\title{
Vitamin D concentrations in Asian children aged 2 years living in England: population survey
}

\author{
Margaret Lawson, Margaret Thomas
}

Editorial by

Wharton

Childhood

Nutrition Research

Centre, Institute of

Child Health,

London

WC1N 1EH

Margaret Lawson, senior lecturer in

paediatric nutrition

Office for National Statistics, London SW1V 2QQ

Margaret Thomas, senior researcher

Correspondence to: Dr Lawson

m.lawson@ich.ucl.ac.uk

BMJ 1999;318:28 Percentage distributior
summary statistics

\begin{tabular}{|c|c|c|c|c|c|}
\hline \multirow[b]{2}{*}{ Vitamin D (nmol/l) } & \multicolumn{3}{|c|}{ Ethnic group } & \multicolumn{2}{|c|}{$\begin{array}{l}\text { National diet and nutrition } \\
\text { survey }^{3} \text { (data on children aged } \\
1.5-2.5 \text { years) }\end{array}$} \\
\hline & $\begin{array}{c}\text { Bangladeshi } \\
(\mathrm{n}=139)\end{array}$ & $\begin{array}{c}\text { Pakistani } \\
(\mathrm{n}=200)\end{array}$ & $\begin{array}{l}\text { Indian } \\
(\mathrm{n}=279)\end{array}$ & $\begin{array}{c}\text { All children } \\
(\mathrm{n}=213)\end{array}$ & $\begin{array}{l}\text { Subgroup } \\
(n=76)^{\star}\end{array}$ \\
\hline$<12.5$ & 0 & 0 & 0 & 0 & 0 \\
\hline$<20.0$ & 13 & 18 & 13 & 0 & 0 \\
\hline$<25.0$ & 20 & 34 & 25 & 1 & 1 \\
\hline$<50.0$ & 69 & 81 & 70 & 17 & 13 \\
\hline$<75.0$ & 91 & 95 & 89 & 64 & 64 \\
\hline$<100.0$ & 99 & 99 & 96 & 93 & 94 \\
\hline$<150.0$ & 100 & 100 & 100 & 100 & 100 \\
\hline Mean & 42.1 & 36.2 & 42.2 & 67.4 & 67.4 \\
\hline Median & 37.5 & 30.0 & 37.5 & 67.5 & 65.0 \\
\hline Lower 2.5 centile & 16.5 & 14.5 & 14.7 & 27.5 & 29.2 \\
\hline Upper 2.5 centile & 91.2 & 92.5 & 102.5 & 155.0 & 121.1 \\
\hline$\overline{\mathrm{SE}}$ & 1.8 & 1.4 & 1.3 & 1.5 & 2.3 \\
\hline$\overline{S D}$ & 21.3 & 19.6 & 22.5 & 21.8 & 19.8 \\
\hline
\end{tabular}

${ }^{*}$ Children aged 1.5-2.5 years who were sampled from October to December.

The Social Survey Division of the Office for National Statistics on behalf of the Department of Health carried out a survey between 1994 and 1996 of infant feeding practices of mothers of Bangladeshi, Indian, or Pakistani origin living in England. ${ }^{1}$ A blood sample was taken during October-November 1996 from a subsample of children aged 2 years for analysis of iron and 25-hydroxycholecalciferol (vitamin D) concentrations. Details for iron concentration are published elsewhere. ${ }^{12}$ We here report the vitamin $\mathrm{D}$ concentration.

\section{Subjects, methods, and results}

Vitamin D concentration was measured in 618 of the children. No evidence was found of bias influencing the selection of this subgroup, which seems to be representative of Asian children in England. The table shows serum 25-hydroxycholecalciferol concentrations for the three groups in comparison with data from the national diet and nutrition survey of preschool children. ${ }^{3}$ Between $20 \%$ and $34 \%$ of children in the three ethnic groups had values of vitamin D below $25 \mathrm{nmol} / \mathrm{l}$, a value considered to indicate deficiency, ${ }^{4}$ and $13-18 \%$ had values below $20 \mathrm{nmol} / \mathrm{l}$; the percentages in the national survey were $1 \%$ and $0 \%$ respectively. Between $20 \%$ and $29 \%$ of children in the study had a haemoglobin concentration $<110 \mathrm{~g} / 1 .{ }^{2}$ All children in the study were apparently healthy, and none had been diagnosed as having rickets. At the age of 2 about $25 \%$ of children were given the Department of Health's recommended vitamin drops, which contain vitamins $\mathrm{A}, \mathrm{C}$, and $\mathrm{D}$. In the national survey less than $5 \%$ were given such drops. ${ }^{3}$

Multiple regression analysis showed for all groups that the concentration of vitamin $\mathrm{D}$ was associated with whether children were given vitamin supplements. In bivariate analysis, failure to take a vitamin supplement,

Percentage distribution of serum 25-hydroxycholecalciferol concentrations with
Clinical review p 39 a haemoglobin concentration of less than $110 \mathrm{~g} / \mathrm{l}$, and a ferritin value of less than $10 \mu \mathrm{g} / \mathrm{l}$ were associated with vitamin D concentrations lower than $25 \mathrm{nmol} / \mathrm{l}$.

\section{Comment}

Rickets has been recognised as a problem in children of Asian immigrants since the 1960s, but, although the Stop Rickets campaign (which encouraged vitamin supplementation) seemed to decrease the incidence of rickets in some regions, no national evaluation of its effectiveness has been carried out. Our data suggest that matters have improved slightly in Bangladeshi and Indian children but not in Pakistani children. Serum vitamin $\mathrm{D}$ concentrations show a seasonal variation, with lowest values early in the year. ${ }^{3}$ Therefore the October values for these children are likely to drop further to those associated with rachitic bone changes in a higher proportion of children.

Some confusion exists among healthcare professionals about the necessity for vitamin supplementation after the age of 1 year, although the Department of Health recommends supplements for all children up to the age of 5 . Those working with ethnic minority groups must deliver a clear message that a vitamin $\mathrm{D}$ supplement is essential for all Asian children under 5 .

A high degree of association between iron deficiency anaemia and vitamin $\mathrm{D}$ deficiency has been reported previously. ${ }^{5}$ A fifth of British Asian children surveyed showed signs of both deficiencies, and during the winter $50 \%$ of children with low vitamin $\mathrm{D}$ had low haemoglobin compared with none with normal vitamin D. In our study, iron deficiency was a significant risk factor for low vitamin D concentration in all three ethnic groups. This high association should alert clinicians to recommend a vitamin $\mathrm{D}$ supplement and screening for rickets in children with low haemoglobin concentrations.

We thank colleagues in the Social Survey Division of the Office for National Statistics, the interviewers, phlebotomists, and especially the families who participated in the study.

Contributors: ML coordinated the blood collection and laboratory analysis; MT coordinated the data collection and analysis. ML and MT wrote the manuscript. Ann Hardiman (Nutrition Unit, Institute of Child Health) managed the practical aspects of blood collection, and Vivienne Avery (Office for National Statistics) helped with data management. Plasma 25-hydroxycholecalciferol concentrations were measured by the Department of Chemical Pathology, Leicester Royal Infirmary, Leicester.

Funding: The study was funded by the Department of Health, whose staff also provided support.

Conflict of interest: None.

1 Thomas M, Avery V. Infant feeding in Asian families. London: Stationery Office, 1997.

2 Lawson M, Thomas M, Hardiman A. Iron status of children aged two years living in England. Arch Dis Child 1998;78:420-6.

3 Gregory JR, Collins DL, Davies PS, Hughes JM, Clarke PC. National diet and nutrition survey: children aged 1/1/2 to 41/2 years. Vol 1. Report of the diet and nutrition survey. London: HMSO, 1995.

4 Arnaud SB, Stickler GB, Haworth JC. Serum 25-hydroxyvitamin D in infantile rickets. Pediatrics 1976;57:221-5.

5 Grindulis H, Scott PH, Belton NR, Wharton BA. Combined deficiency of iron and vitamin D in Asian toddlers. Arch Dis Child 1986;61:843-8. (Accepted 8June 1998) 